\title{
Dampak Covid 19 Serta Kedudukan Surat Keterangan Dokter Sebagai Pengecualian Atas Ketidakhadiran Tersangka Dalam Persidangan Kasus Korupsi
}

\author{
Irsyad Zamhier Tuahuns \\ Program Magister Ilmu Hukum Universitas Padjadjaran Bandung \\ Email: ichattuahuns@gmail.com
}

Rahmat Kurnain Rumadaul

Program Magister Ilmu Hukum Universitas Padjadjaran Bandung Email :

Abstrak: $\quad$ The Covid-19 pandemic in Indonesia has limited the space for the community, including the ranks / elements of the criminal justice system, especially in eradicating corruption, because everyone is very afraid of being exposed to Covid-19. Diversion and deviation of Doctor's Certificate will easily occur. There is a strong tendency among law enforcers that a doctor's certificate is strong evidence, and cannot be contested. law enforcement on corruption in Indonesia, law enforcers have not civilized the culture of examining and ensuring that doctor's certificates are genuine or fake and can be accounted for scientifically and professionally. In addition, I have never asked for a second opinion from another doctor, to check the health of a person who is declared sick and unable to attend the trial process, from a previous doctor.

Kata Kunci: deviation of letters, trial corruption

Abstract: Pandemi Covid-19 di Indonesia telah membatasi ruang gerak masyarakat, termasuk jajaran/unsur sistem peradilan pidana, khususnya dalam pemberantasan korupsi, karena semua orang sangat takut terpapar Covid- 
19. Penyelewengan dan penyimpangan Surat Keterangan Dokter akan mudah terjadi. Terdapat kecenderungan kuat di kalangan penegak hukum, bahwa surat keterangan dokter merupakan alat bukti yang kuat, dan tidak dapat diganggu gugat. penegakan hukum tindak pidana korupsi di Indonesia, penegak hukum belum membudayakan pemeriksaan dan memastikan surat keterangan dokter asli atau palsu serta dapat dipertanggungjawabkan secara ilmiah dan profesional. Di samping itu, juga belum pernah meminta second opinion dari dokter yang lain, untuk memeriksa kesehatan seseorang yang dinyatakan sakit dan berhalangan untuk hadir dalam proses peradilan, dari dokter sebelumnya.

Keywords: Penyimpangan surat, sidang,korupsi

\section{PENDAHULUAN}

Dalam sejarah yang terjadi di negara Indonesia dalam penanggulangan pekara tindak pidana korupsi memang memiliki persoalan yang mendasar yaitu tentang penangulanganya, berdasarkan fenomena yang terjadi para terdakwa, tersangka selalu mencari alasan agar dapat terhindar dari proses pemeriksaaan maupun tahap persidangan. Persoalan dalam penegakan hukum kita sering mendapatkan informasi melalui sarana tekonologi sehingga kita dapat mengetahui bahwa pemerintah dalam memerangi kasus tindak pidana korupsi selalu secara transparan terhadap publik mengenai ketersediaanya informasi yang kredibel dan terpercaya. Kasus korupsi triliun yang kita ketahui banyak menyeret mantan petingi atau pejabat di negara ini seperti Edy tansil, Bambang W. Soeharto. ${ }^{1}$ serangkaian pengecualian yang di lakukan oleh terdakwa, tersangka sebagai alasan agar terhindar dari proses pemeriksaan di tahap kepolisian, kejaksaan, dan persidangan hal ini sangat kita ketahui bersama dengan menyertakan indentik keterangan dokter sebagai pertimbangan hakim, jaksa, polisi sampai tingkat lembaga pemasyarkatan dalam proses penahanan.

Negara Indonesia pernah di buat viral dengan kaburnya terpidana kasus korupsi yaitu edy tansil dari Lembaga

\footnotetext{
1 Indriyanto Seno Adji, Humanisme Dan Pembaruan Penegakan Hukum (Jakarta: Penerbit Buku Kompas, 2009), hal. 150.
} 
Pemasyarakatan Cipinang ke Rumah Sakit Polri di era kepemimpinan presiden soeharto dengan hanya selembar kertas putih keterangan dokter yang mengakibatkan penahanan menjadi ancaman bagi pemerintah, hal ini dapat menjadi angapan oleh masyarakat bahwa parah penegak hukum tidak serius dalam menangani terpidana kasus korupsi, ini merupakan kelemahan pemerintah dalam berupaya menangulangi para koruptor.

Kasus setya novanto termasuk persoalan yang menjadi sorotan publik seperti tema yang di ambil penulis yaitu adanya upaya menghindari pemeriksaan KPK terhadap tersangka kasus korupsi. Seringkali surat keterangan dokter menjadi alternative agar pelaku terhindar dari proses pemeriksaan. Melalui proses, dramatisirnya setya novanto mengalami kecelakaan mobil sehingga tersangka di rawat, ini merupakan serangkaian pengalihanya agar proses pemeriksaan dapat memakan waktu yang lama, mengenai kebijakan rumah sakit serta seorang ahli (dokter) merupakan yang paling bertanggung jawab atas pasien yang di tanganinya apakah sesuai dengan keadaan tertentu ataukah indikasi bekerjasama. Seperti kita ketahui setiap dokter perlu di sumpah sehingga menjalankan tugas dan tanggungjawabnya dapat sesuai dengan amanat PP No. 26 Tahun 1960.

Prespektif umum korupsi merupakan suatu kejahatan yang di sebut sebagai (extra ordinary crime) menurut Mark hal tersebut merupakan kejahatan luar biasa dalam tindakanya memerlukan (SDM) sumber daya manusia yang memiliki keahlian serta tersertifikasi dalam bidang ilmu hukum. Adapaun istilah kejahatan serius yaitu kejahatan yang mengancam kemanan, perdamaian, kesejahteraan dan kehidupan manusia. Kejahatan luar biasa harus memenuhi 3 karakter yaitu:

1) dilakukan secara terencana

2) terorganisir

3) sistematis $^{2}$

Tolak ukur korupsi sebagai tindak pidana luar biasa adalah bersifat sistematik, endemik dan dampaknya sangat luas (systematic dan widespread) yang dalam persoalanya tidak hanya

2 Eddy 0,s Hiariej, Pembuktian terbalik dalam Pengembalian Asset Kejahatan Korupsi, Pidato Pengukuhan Jabatan Guru Besar pada Fakultas Hukum Universitas Gadjah Mada, Rapat Terbuka Majelis Guru Besar Universitas Gadjah Mada pada tanggal 30 Januari 2012 di Yogyakarta, hlm, 3. 
merugikan keuangan negara tetapi dapat melanggar hak sosial serta ekonomi masyarakat luas sehingga dalam upayanya memerlukan comprehensive extra ordinanry measure. Maka dalam hal memerangi tindak pidana korupsi di perlukan dari segi kualitas dan kuantitas. $^{3}$

Fenomenal yang terjadi akhir ini adalah pemanfaatan surat keterangan dokter dalam upaya memperlamabat proses pemeriksaan, penangkapan. Sering kita jumpai, keterkaitan oknum dokter dalam melampirkan surat yang tidak sesuai dengan keadaan terjadi pada pasien menginialisasikan bahwa dokter melanggar hukum serta ketentuan pidana, dan strategi seperti ini akan terus berlangsung apalagi adanya wabah Covid 19 di seluruh dunia ini menjadi kehati-hatian bagi pemerintah, alasanya para koruptor dapat berdalih perihal kesehatanya maka berdampak juga pada proses penegakan hukum.

Peran kedudukan 4 pilar yaitu: Hakim, jaksa, polisi, advocat merupakan instrument pemerintah dalam penegakan hukum tentunya memiliki peran penting dalam memutus mata rantai praktik-praktik korupsi. Dalam upaya mewujudkan system hukum nasional berlandaskan dengan keadilan maka perlu di kembangkan budaya hukum di seluruh lapisan masyarakat. Beberapa ahli yang mengemukakan penegak hukum perlu di tanamkan "morality" dengan demikian ketika moralitas penegak hukum seudah sangat baik maka hukum akan di tegakan sesuai dengan amanat konstitusional.

Penelitian terkait dengan Covid 19 di Indonesia serta kekuatan surat keterangan dokter sebagai pengecualian atas ketidak hadiran tersangka dalam proses persidangan kasus korupsi bukanlah penelitan yang baru dilakukan, karena berdasarkan penelusuran di beberapa kepustakaan,jurnal terdahulu hampir sama. Yaitu aspek hukum surat keterangan dokter dalam sistem peradilan pidana yang dilakukan oleh Badan Pembinaan Hukum Nasional (BPHN) pada Tahun 2002.

Berdasarkan latar belakang di atas identifikasi penelitian untuk jurnal ini di rumuskan sebagai berikut:

\footnotetext{
3 Romli atmasasmita, Korupsi, Good Governance dan komisi Anti Korupsi Di Indonesia, Penerbit Badan Pembinaan Hukum Nasional Departemen Kehakiman dan HAM RI, Jakarta, 2002, hlm, 25.
} 
1. Apakah dengan menerbitkan surat keterangan dokter dapat mempengaruhi proses penegakan hukum terhadap tersangka kasus korupsi?

2. Bagaimanakah implementasi hukum pidana terhadap dokter yang memberikan surat keterangan yang tidak sesuai dengan kebenaranya dalam proses pembuktian?

\section{METODE}

Metode yang dipakai dalam penulisan jurnal ini adalah yuridis normative menurut Mochtar Kusumatmadja mengatakan bahwa selain ketertiban, tujuan lain dari hukum adalah tercapainya keadilan yang berbeda-beda isi dan ukuranya menurut masyarakat dan zamanya. Untuk mencapai ketertiban masyarakat. ${ }^{4}$ Konsepkonsep pemikiran hukum yang telah dikembangkan Mochtar Kusumatmadja, yang lebih dikenal dengan mazhab unpad. ${ }^{5}$ Mengatakan bahwa hukum adalah sebagai sarana pembangunan, berarti pembinaan hukum nasional harus di lakukan dengan tetap memperhatikan kesadaran hukum masyrakat, dengan kata lainya setiap Undang-undang yang berlaku hendaknya dapat diselaraskan dengan kesadaran hukum masyarakat di Indonesia. Mochtar kusumatmadja telah mengubah pengertian hukum sebagai alat (tool) hukum sebagai instrument untuk membangun masyrakat.

Menurut soerjono soekanto ada beberapa faktor yang perlu di perhatikan dalam proses penegakan hukum: ${ }^{6}$

1. Faktor Undang-undang

2. Faktor Penegakan Hukum

3. Faktor sarana dan fasilitas

4. Faktor Masyarakat

5. Faktor Kebudayaan.

\footnotetext{
${ }^{4}$ Mochtar Kusumatmadja. (editor; R Otje Salman. Dan Edi Damian). Konsepkonsep dalam Pembangunan: Kumpulan

${ }^{5}$ Lili Rasjidi dan I.B Wyasa, Hukum sebagai suatu Sistem. Bandung : Mandar Maju, $2003 \mathrm{hlm} .182$

6 Soerjono Soekanto. Faktor-Faktor yang mempengaruhi Penegakan Hukum. Jakarta: raja Grafindo Persada, 2005, hlm 8-10.
} 


\section{HASIL DAN PEMBAHASAN}

Penegakan hukum pada dasarnya ialah sebagai salah satu upaya untuk tercapainya kepastian hukum serta keadilan. Pendapat Roscou Pound adalah bahwa hukum merupakan fungsi untuk memenuhi berbagai kepentingan penyelenggara negara atau pemerintah yaitu kepentingan individual (Individual interest) dan juga kepentingan masyarakat (social interest). Kategori ini dapat di simpulkan bahwa hukum ialah sarana kepentingan bagi masyarakat baik individual atau bersama (social instrument) dan kepentingan hukum hanya bagi penyelenggara (power instrument).

Dalam proses mencapaianya kepastian hukum serta keadilan hukum dalam penegakan masih belum mencapai yang sesuai dengan keinginan masyarakat, karena hukum hanya berdiri tegak kepada kekuasaan dan tumpul kepada golongan yang lemah. Pembedaan inilah yang mengakibatkan ketidak percayaan masyarakat terhadap para pemerintah. Dimasa kolonial hukum sebagai alat untuk menindas golongan masyarakat yang lemah terhadap hukum. Semasa orde baru hukum hanya menindas golongan lemah dan hanya memuaskan bagi kekuasaan serta kepentingan para elit politik. Hukum akan mendapatkan arti setelah penegakan hukum berjalan sesuai dengan amanat konstitusional. Demikian untuk menegakan hukum perlu adanya kekuasaan sebab tanpa kekuasaan hukum itu hanya angan-angan. ${ }^{7}$

Surat keterangan dokter adalah surat atau tulisan yang dibuat dengan kertas dan yang berhak mengeluarkanya adalah dokter dengan isinya merupakan menjelaskan secara detail kesehatan pasien yang di periksa guna menerangkan kondisi pasien yang di alami secara benar adanya. Mengenai alat bukti serta keabsahan keterangan dokter dalam ketentuan hukum pidana perbuatan dokter yang memberikan surat keterangan sakit kepada pasienya dan tidak melakukan pemeriksaan dengan sebenarnya terhadap pasien tersebut maka perbuatan dokter tersbut melanggar kode etik kedokteran Indonesia secara tidak langsung dalam hal ini ialah merupakan perbuatan pidana dalam proses mengahalngi pelaku tindak pidana korupsi dan merupakan sifat melawan hukum. ${ }^{8}$ Sesuai

\footnotetext{
${ }^{7}$ Mochtar Kusumatmadja, Fungsi dan Perkembangan Hukum dalam Pembangunan Nasional, Bina Cipta, Bandung, tt, ,hlm 5

8 J. E. Sahetapy, Liberty Yogyakarta,hlm 27.
} 
Peraturan pemerintah Nomor 26 Tahun 1960 setiap dokter harusnya mengamalkan ketentuan tersebut.

\section{Alat bukti}

Dalam hukum acara pidana dapat di kemukakan pada alat bukti yang sah yaitu:

1) Keterangan saksi

2) Keterangan ahli

3) Surat

4) Petunjuk

5) Keterangan terdakwa ${ }^{9}$

Mengenai proses peradilan pidana yang mempunyai fungsi yang semata-mata mencari kebenaran materil dengan tidak mengorbankan tersangka sehingga orang yang bersalah dan tidak bersalah dapat di benarkan keteranganya berlandaskan minimal 2 (dua) alat bukti yang sah berdasarkan pasal 183 KUHP.

2. Visum et Repertum

Visum et repertum adalah suatu laporan medik forensic oleh seorang dokter berdasarkan sumpah jabatanya terhadap pemeriksaanya barang bukti medis (hidup/mati) atau barang bukti lain untuk kepentingan proses penyedikan hingga persidangan. Visum repertum merupakan bukti tertulis dari dokter (ahli) yang di buat berdasarkan sumpah yaitu di lihat dan di temukanya berdasarkan keahlianya.

\section{Prosedur permohonan visum et repertum}

Memberikan keterangan di depan siding pengadilan bagi ahli kedokteran kehakiman khususnya ahli lain pada umumnya, serta setiap orang merupakan suatu suatu kewajiban. Pelangaran terhadap kewajiban ini akan di ancam sesuai ketentuan hukum. ${ }^{10}$ Ketentuan dalam hukum pidana seperti kita ketahui barang siapa dengan sengaja mengunakan wewenangya/keahlianya untuk melakukan suatu pemufakatan jahat dalam memberikan suatu keterangan palsu maka akan di tuntut dengan pidana persoalan seperti yang di jabarkan di atas adalah suatu perbuatan yang melawan hukum sesuai dengan Pasal 276.

Delik dalam Pasal 267 ini adalah delik sengaja. Dokter atau ahli dalam bidangnya yang membuat surat keterangan palsu untuk tujuan yang tidak di benarkan sesuai atau tidak di alami

\footnotetext{
${ }^{9}$ Pasal 184 ayat (1) KUHP

${ }^{10}$ Pasal 224 KUHPidana
} 
oleh orang bersangkutan dipidana lebih berat, yaitu maksimum delapan tahun enam bulan penjara, delik pada Ayat (1) empat tahun penjara. Ini yang menjadei persoalan jika keahlian seseorang di lakukan dengan tidak semestinya.

Akhir ini persidangan kasus korupsi hingga kasus serupa banyak di persidangkan surat keterangan dokter menjadi dasar alasan yang tidak di benarkan untuk menghindari proses persidangan terkadang trersangka diharuskan melakukan perbaikan kesehatan yang di rujukan ialah luar negeri. Undangundang terkait keterangan dokter tercantum di dalam pasal 48 . Undang-undang Nomor 36 Tahun 2009 tentang kesehatan di tuangkan dalam pasal 20,pasal 22 pasal 23 pasal 24 . Problematiak dalam proses penegakan hukummelihat dan mendasarkan pada para pihak terkait tindak pidana korupsi yang mempunyai Surat Keterangan Dokter (sakit) dalam proses pemeriksaan sampai dengan di persidangan, menjadi lebih kompleks apabila para pihak terkait tersebut, terutama saksi yang memberatkan, kemudian tersangka, tertuduh, dan terdakwa tibatiba menderita stroke berat, dan gangguan jiwa. Dalam Undang-undang Nomor 18 Tahun 2014 Tentang Kesehatan Jiwa ditegaskan:

\section{Pasal 71}

1. Untuk kepentingan dalam penegakan hukum seseorang diduga ODGJ yang melakukan tindak pidana harus mendapatkan pemeriksaan kesehatan jiwa.

2. Pemeriksaan Kesehatan Jiwa sebagaimana dimaksud pada Ayat(1) dilakukan untuk: a. Menentukan kemampuan seseorang dalam mempertanggung jawabkan tindak pidana yang telah dilakukannya; dan/atau b. Menentukan kecakapan seseorang untuk mengikuti prosenya peradian.

Pasal 72

(1) Untuk kepentingan keperdataan, seseorang yang diduga kehilangan kecakapan untuk melakukan perbuatan hukum mendapatkan pemeriksaan kesehatan jiwa;

(2) Prosedur penentuan kecakapan untuk melakukan perbuatan hukum sebagaimana dimaksud padaAyat(1) dilaksanakan sesuai dengan procedural.

Pasal 73 
1. Pemeriksaan kesehatan jiwa kepentingan hukum sebagaimana dimaksud dalam Pasal 71 dan Pasal 72 dilakukan oleh Tim;

2. Tim sebagaimana dimaksud pada Ayat (1) diketuai oleh dokter spesialis kedokteran jiwa dan dapat melibatkan dokter spesialis lain, dokter umum, dan/atau psikolog klinis;

3. Ketentuan lebih lanjut mengenai pedoman Pemeriksaan Kesehatan Jiwa untuk kepentinganhukumdiatur denganPeraturan Menteri.

\section{Pertanggungjawaban Secara Pidana}

Tugas kaedah hukum yaitu pemberian kepastian hukum yang tertuju pada ketertiban dan pemberian kesebandingan hukum yang tertuju pada ketenangan atau ketenteraman. Ketertiban tersebut ditandai dengan ciri-ciri sebagai berikut (C.J.M. Schuyt: 1976); dari 16 ciri, diantaranya:

a) Voorspelbaarheid (diperkirakan);

b) Cooperatie (kerjasama);

c) Consistentie (kesesuaian);

d) Conformiteit(ketaatan);

e) Uniformiteit (keseragaman);

f) Gemeenchappelijkheid (kebersamaan);

g) Bevel (perintah);

h) Volgorde (bertahap). ${ }^{11}$

Aspek kepastian hukum, menurut Jan Michiel Otto, kepastian hukum yang sesungguhnya memang lebih berdimensi yuridis. Namun, Otto ingin memberi batasan kepatian hukum yang lebih jauh. Untuk itu ia mendefinisikan kepastian hukum sebagai kemungkinan bahwa dalam situasi tertentu. ${ }^{12}$

a. Tersedia aturan-aturan hukum yang jelas (jernih), konsisten dan mudah diperoleh (accessible), diterbitkan oleh dan diakui karena (kekuasaan) negara;

11 Soerjono Soekanto \& Purnadi Purbacaraka, SendiSendi Ilmu Hukum Dan Tata Hukum (Bandung: Penerbit CitraAditya Bakti, 1993), hal. 9.

${ }^{12}$ Sidharta, Moralitas Profesi Hukum Suatu Tawaran Kerangka Berfikir (Bandung: Penerbit Refika Aditama, 2006), hal. 85 
b. Instansi-instansi penguasa (pemerintahan) hukum tersebut tunduk dan taat menerapkan aturan-aturan secara konsisten dan juga kepadanya;

c. Warga secara prinsipil menyesuaikan perilaku mereka terhadap aturan-aturan tersebut;

d. Hakim-hakim (peradilan) yang mandiri dan tidak berpihak menerapkan aturan-aturan hukum tersebut secara konsisten sewaktu mereka menyelesaikan sengketa hukum; dan Keputusan peradilan secara konkret dilaksanakan.

Penerapan pertanggungjawaban pidana pada pihak-pihak yang menyalahgunakan pembuatan surat keterangan dokter, mutlak diperlukan. Menurut pakar hukum pidana Roeslan Saleh, tiga alasan yang cukup panjang mengenai masih perlunya pidana dan hukum pidana. Adapun inti alasannya adalah sebagai berikut: ${ }^{13}$

a. Perlu tidaknya hukum pidana tidak terletak pada persoalan tujuan-tujuan yang hendak dicapai, tetapi terletak pada persoalan seberapa jauh untuk mencapai tujuan itu boleh menggunakan paksaan. Persoalan bukan terletak pada hasil yang akan dicapai, tetapi dalam perimbangan antara nilai dari hasil itu dan nilai dari batasbatas kebebasan pribadi masing-masing.

b. Ada usaha-usaha perbaikan atau perawatan yang tidak mempunyai arti sama sekali bagi si terhukum; dan disamping itu harus tetap ada suatu reaksi atas pelanggaran-pelanggaran norma yang telah dilakukannya itu dan tidaklah dapat dibiarkan begitu saja.

c. Pengaruh pidana atau hukum pidana bukan semata-mata ditujukan pada si penjahat, tetapi juga untuk mempengaruhi orang yang tidak jahat yaitu warga masyarakat yang norma-normamasyarakat.

\section{Kekuatan Serta Pembuktian surat Keterangan Dokter}

Persoalan penegakan hukum termasuk dalam pemberantasan korupsi, di tahun 2020 sampai dengan waktu yang belum ditentukan mengalami kurve/ trend yang menurun tajam. Pandemi corona yang terjadi di seluruh dunia, termasuk

13 Teguh Prasetyo, Kriminalisasi Dalam Hukum Pidana (Bandung: Penerbit Nusa Media, 2010), hal. 22-23 
Indonesia. Penerapan Pembatasan Sosial Berskala Besar (PSBB) yang pada prinsipnya menekankan Social Distanting dan Psychial Distanting, pada gilirannya harus merubah secara mendasar proses pemeriksaan tersangka, tertuduh, dan terdakwa, bahkan para saksi yang terkait dengan menjaga jarak aman untuk mencegah penularan pandemi covid-19.

Tahapan persidangan melalui daring online pun telah di lakukan agar tetap menjaga protocol kesehatan hal ini merupakan suatu hal yang sulit. Pertanggungjawaban serta etika dokter yang menyalahi wewenanya, penyususnan kode etik merupakan suatu langkah upaya terjadinya pelangaran hukum terhadap oknum dokter maupun tindak pidana yang dilakukan oleh anggotanya. Di mana kode etik mengandung pola aturan, tata cara, tanda pedoman etik ketika melakukan suatu kegiatan atau pekerjaan. ${ }^{14}$

Keaslian surat keterangan dokter menjadi sangat penting, hal ini dikarenakan bahwa dapat terjadi surat keterangan dokter tersebut palsu, ataupun dokter yang membuat surat keterangan sakit, dalam keadaan diintimidasi oleh pihak lain, baik atasan langsung atau pihak lain; sehingga obyektivitasnya sangat diragukan oleh penegak hukum. Sebaliknya, apabila surat keterangan dokter tersebut dibuat atas kerjasama antara dokter dengan pihak orang yang berkepentingan agar terhindar dalam proses penegakan hukum, sudah barang tentu pertanggungjawaban pidana harus dilakukan terhadap dokter yang bersangkutan. Yurisprudensi telah ada di Indonesia, dengan dipidananya dokter yang membuat Setia Novanto untuk menghindari penangkapan dari KPK pada tahun 2018 yang lalu. Keadaan ini untuk menerapkan kepastian hukum dan keadilan.

Meskipun UUD 1945 telah berubah, namun pemahaman atas hukum dan cara menerapkan hukum, terutama akademisi, legislator, penegak hukum, belum banyak mengalami perubahan. Oleh karena itu, hukum di Indonesia saat ini masih memiliki watak konservatif. Kondisi hukum dan penegakan hukum diatas telah melahirkan cara penerapan hukum yang kehilangan sukma, moral, dan keadilan. Hukum berbelok menjadi sematamata urusan formal-prosedural. Nilai-nilai etika, moral, dan keadilan

14 Widyo Pramono, Pemberantasan Korupsi Dan Pidana Lainnya: Sebuah Perspektif Jaksa Dan Guru Besar (Jakarta: Penerbit Buku Kompas, 2016)hal. 328 329. 
sering kali diabaikan. Jika ditarik ke permasalahan yang mendasar, masih terdapat ambiguitas konsepsi yang dianut, rechtsstaat yang kepastian hukum dan konsepsi negara hukum mengedepankan the rule of law yang menekankan pada rasa keadilan. ${ }^{15}$

\section{PENUTUP}

Pandemi Covid-19 di Indonesia telah membatasi ruang gerak masyarakat, termasuk jajaran/unsur sistem peradilan pidana, khususnya dalam pemberantasan korupsi, karena semua orang sangat takut terpapar Covid-19. Penyelewengan dan penyimpangan Surat Keterangan Dokter akan mudah terjadi. Terdapat kecenderungan kuat di kalangan penegak hukum, bahwa surat keterangan dokter merupakan alat bukti yang kuat, dan tidak dapat diganggu gugat. penegakan hukum tindak pidana korupsi di Indonesia, penegak hukum belum membudayakan pemeriksaan dan memastikan surat keterangan dokter asli atau palsu serta dapat dipertanggungjawabkan secara ilmiah dan profesional. Di samping itu, juga belum pernah meminta second opinion dari dokter yang lain, untuk memeriksa kesehatan seseorang yang dinyatakan sakit dan berhalangan untuk hadir dalam proses peradilan, dari dokter sebelumnya.

Berdasarkan uraian dalam pembahasan di atas maka dapat disimpulkan dalam kaitanya tentang pembuktian hukum dari keterangan tersangka dengan mengunakan surat keterangan dokter bukanlah merupakan suatu alasan ketidak hadiran tersangka. Jika ini tidak di sikapi dengan menjujung kepastian hukum maka akan berdampak pada kasus yang serupa. Proses pemeriksaan di tingkat kepolisan hingga persidangan dan penahanan, ini merupakan suatu hal yang mutlak jika ketidak hadiran tersangka dalam proses persidangan, (in abstenia) bukan merupakan sah atau tidaknya proses persidangan. Dalam konteks pemasyarakatan bagi tersangka tidak di wajibkan untuk tersangka menjalani pemeriksaan kesehatan hingga keluar dari negara yang menjadi penahananya. Ini merupakan suatu kekeliruan dan menjadi persoalan yang sangat urgent jika tersangka dengan alasan bahwa di perlukan untuk melakukan pengobatan jika diketahui terjadi suatu hal yang

15 Zainal Arifin Hoessein, Mahkamah Agung Dan Perubahan Hukum Dalam Akuntabilitas Mahkamah Agung, ed. Theo Yunus dan Hermansyah (Jakarta: PenerbitAPPTHI \& Rajawali Press, 2016), hal. 45 
berdampak pada kaburnya tersangka maka ini akan menjadi penilaian public terhadap pemerintah dalam hal keseriusan dalam menangani tersangka tindak pidana korupsi. 


\section{DAFTAR PUSTAKA}

Indriyanto Seno Adji, Humanisme Dan Pembaruan Penegakan Hukum (Jakarta: Penerbit Buku Kompas, 2009), hal. 150.

Eddy 0,s Hiariej, Pembuktian terbalik dalam Pengembalian Asset Kejahatan Korupsi, Pidato Pengukuhan Jabatan Guru Besar pada Fakultas Hukum Universitas Gadjah Mada, Rapat Terbuka Majelis Guru Besar Universitas Gadjah Mada pada tanggal 30 Januari 2012 di Yogyakarta, hlm, 3.

Romli atmasasmita, Korupsi, Good Governance dan komisi Anti Korupsi Di Indonesia, Penerbit Badan Pembinaan Hukum Nasional Departemen Kehakiman dan HAM RI, Jakarta, 2002, hlm, 25.

Mochtar Kusumatmadja. (editor; R Otje Salman. Dan Edi Damian). Konsep-konsep dalam Pembangunan: Kumpulan

Mochtar Kusumatmadja. (editor; R Otje Salman. Dan Edi Damian).

Konsep-konsep dalam Pembangunan: Kumpulan

Lili Rasjidi dan I.B Wyasa, Hukum sebagai suatu Sistem. Bandung : Mandar Maju, $2003 \mathrm{hlm} .182$

Soerjono Soekanto. Faktor-Faktor yang mempengaruhi Penegakan Hukum. Jakarta: raja Grafindo Persada, 2005, hlm 8-10.

Soerjono Soekanto \& Purnadi Purbacaraka, SendiSendi Ilmu Hukum Dan Tata Hukum (Bandung: Penerbit CitraAditya Bakti, 1993), hal. 9.

Sidharta, Moralitas Profesi Hukum Suatu Tawaran Kerangka Berfikir (Bandung: Penerbit Refika Aditama, 2006), hal. 85

Teguh Prasetyo, Kriminalisasi Dalam Hukum Pidana (Bandung: Penerbit Nusa Media, 2010), hal. 22-23

Zainal Arifin Hoessein, Mahkamah Agung Dan Perubahan Hukum Dalam Akuntabilitas Mahkamah Agung, ed. Theo Yunus dan Hermansyah (Jakarta: PenerbitAPPTHI \& Rajawali Press, 2016), hal. 45

Widyo Pramono, Pemberantasan Korupsi Dan Pidana Lainnya: Sebuah Perspektif Jaksa Dan Guru Besar (Jakarta: Penerbit Buku Kompas, 2016)hal. 328-329.

J. E. Sahetapy, Liberty Yogyakarta,hlm 27

Pasal 184 ayat (1) KUHP

Pasal 224 KUHPidana 